\title{
АДМІНІСТРАТИВНО-ПРАВОВІ АСПЕКТИ ФОРМУВАННЯ СИСТЕМИ ПРИНЦИПІВ УПРАВЛІННЯ СЕКТОРОМ БЕЗПЕКИ УКРАЇНИ
}

Гончаренко Г. А.

\begin{abstract}
У статті досліджено сутність і зміст системи принципів управління сектором безпеки України та критеріі їх класифікації. Здійснено аналіз системи принципів, що діють у сфері національної безпеки, принципів діяльності Служби безпеки України, а також принципів розвитку сектору безпеки і оборони в співвідношенні з принципами управління сектором безпеки. Запропоновано власне визначення поняття «принципи управління сектором безпеки» та здійснено їх авторський розподіл. Зроблено висновок про необхідність удосконалення підходів до формування принципів управління сектором безпеки України.

Ключові слова: поняття, класифікація, принципи управління, сектор безпеки України, адміністративно-правове регулювання.
\end{abstract}

В статье исследованы суть и содержание системы принципов управления сектором безопасности Украины и критерии их классификации. Осуществлен анализ системы принципов, которые действуют в сфере национальной безопасности, принципов деятельности Службы безопасности Украины, а также принципов развития сектора безопасности и обороны, в соотношении с принципами управления сектора безопасности. Предложено собственное определение «принципы управления сектором безопасности» и авторский подход к их классификации. Сделан вывод о необходимости совершенствования подходов к формированию принципов управления сектором безопасности Украины.

Ключевые слова: понятие, классификация, принципы управления, сектор безопасности Украины, административно-правовое регулирование.

The article is devoted to the study of the system of principles for managing the security sector in the framework of administrative regulation. It has been established that the legal principles of security sector management, expressed in the form of a certain scientific position, ensure the activities of its subjects, is the basis for the fulfillment of their tasks and the content of managerial decisions made. A complete analysis of the system of principles in the field of national security, the principles of the Security Service of Ukraine, as well as the principles of development of the security and defense sectors in relation to the principles of management of the security sector. It is argued that the principles of management of the security sector of Ukraine are legal, in most cases they stem from individual legal norms. It is determined that in the content of the principles of management of the security sector of Ukraine there are three interrelated and interdependent aspects: 1) ontological; 2) epistemological; 3) methodological.

It is analyzed that scientific papers distinguish between management principles (socio-political, structural principles of managerial activity), or principles (management, organization, motivation and control) or principles of general management principles at the industry level (industry principles) or

Гончаренко Г. А., 2019 at the status level - institutional, organizational , group and principles directly related to the activities of entities implementing management, etc.

It is determined that the principles of management in the security sector of Ukraine can be system-wide (legality, objectivity, consistency, completeness, comprehensiveness, transparency, the rule of law, accountability, legality, transparency, social orientation, objectivity, complexity, consistency and transparency of respect for the rights and dignity of the individual, openness to democratic control, compliance with international law), structural (systemic principle, territoriality principle) and specialized (combination of one-man management and collegial, c entralizatsii leadership, discipline), etc .. It has been established that the above list of principles for managing the security sector of Ukraine in the article is not exhaustive, since the management of the security sector is a multifaceted activity and has a multi-subject composition, since the "security sector" is a set of government bodies and organizations that are called upon to ensure the safety of individuals, society and the state.

Attention is focused on the fact that in the framework of managing the security sector of Ukraine, the principles determine the requirements for the system, structure, organization and management process, designed to reflect the laws objectively existing in the legal regulation, which are of particular importance for the organization and implementation of security of the individual, society and the state. It is recognized that the improvement of management principles in the security sector of Ukraine should be comprehensive, form the right approaches to creating basic ideas for its construction and meet the requirements of administrative legal doctrine and practice.

Key words: concept, classification, management principles, security sector of Ukraine, administrative regulation.

Постановка проблеми та її актуальність. Однією із невирішених проблем управлінської діяльності $€$ проблема щодо встановлення єдиного підходу до визначення та переліку принципів [1, с. 12], в тому числі і у секторі безпеки України. Система правових принципів, на якій ґрунтуються управлінські відносини сектору безпеки України, закладає основу його розвитку. Необхідність гарантування дотримання цього правового базису зумовлює актуальність дослідження принципів управління сектором безпеки України, адже саме їх формування впливає і на подальший розвиток держави, державної влади та суспільства.

Аналіз останніх досліджень і публікацій. Дослідженням окремих аспектів регулювання управлінських правовідносин займалися такі українські та зарубіжні вчені, як О. Андрійко, Г. Атаманчук, В. Авер'янов, Ю. Битяк, Н. Матюхіна, Ю. Шемшученко, О. Шевчук та інші. Принципи ж управління були предметом досліджень у сфері державного управління в роботах таких вчених, як Д. Талалай, О. Шаптала, О. Радченко. 
Ці автори згрупували та сформулювали основні принципи управління оперативно-службовою діяльністю Служби безпеки України, виокремили їх особливості та окремі ознаки [2]. А.М. Сіцінська виокремила перелік основних принципів державного управління у сфері демократичного цивільного контролю над сектором безпеки і оборони України [3]. С. Мельник з'ясував адміністративно-правові аспекти принципів військового управління [4]. В. Антонов звернув увагу на місце та роль загальних (діалектико-матеріалістичних) принципів у системі забезпечення національної безпеки [5]. С. Пономарьов розглянув систему та зміст принципів суб' єктів сектора безпеки і оборони [6, с. 12] та інші. Однак, аналізуючи спеціалізовану юридичну літературу, можна дійти висновку, що належної уваги вивченню принципів управління сектором безпеки України на доктринальному рівні з позицій адміністративно-правової науки не приділялося. Зазначене вище зумовлює актуальність тематики цієї статті та створює передумови для подальших досліджень.

Мета статті - аналіз особливостей та сутності, ознак та класифікації принципів сектору безпеки України, а також вироблення пропозицій щодо їх систематизації.

Виклад основного матеріалу. Категорія «управління» являє собою діяльність уповноважених органів, що спрямована на досягнення конкретних завдань за допомогою управлінських методів, способів та функцій [7, с. 10]. Відповідно до ст. 1 Закону України «Про національну безпеку України» визначено правову конструкцію «сектор безпеки і оборони». Передбачено, що їх діяльність перебуває під демократичним цивільним контролем і відповідно до Конституції та законів України за функціональним призначенням спрямована на захист національних інтересів України від загроз (п. 16) [8]. Також до системи сектору безпеки і оборони законодавець відносить громадян та громадські об'єднання, які добровільно беруть участь у забезпеченні національної безпеки України. Зазначимо при цьому, що в загаданому законодавчому акті немає окремого поняття «сектор безпеки».

У наукових джерелах під терміном «сектор безпеки» розуміють сукупність державних органів та організацій, які покликані гарантувати безпеку особи, суспільства та держави. До елементів сектору безпекиУкраїни відносять: особисту безпеку громадян, громадську безпеку; державну безпеку; військову безпеку [9]. Інші автори пропонують ці елементи сектору безпеки доповнити економічною, соціальною, екологічною, політичною безпекою, оскільки саме ці види безпеки і визначають рівень розвитку держави, захищеність населення [10].

Будь-яка модель управління, в тому числі і в секторі безпеки України, враховує основні принципи управління, стратегічне бачення, цілі й завдання, організаційну структуру i порядок взаємодії іï елементів $[11$, с. 157]. Стосовно визначення змісту терміну «принцип». Так, у юридичних енциклопедичних джерелах принципи (від фр. “principe”, lat. "principium” - начало, основа) визначаються як: «(а) основні засади, вихідні ідеї, що характеризуються універсальністю, загальною значущістю, вищою імперативністю і відображають суттєві положення теорії, вчення, науки, системи внутрішнього й міжнародного права, політичної, державної чи громадської організації; (б) внутрішнє переконання людини, що визначає їі ставлення до дійсності, суспільних ідей...» $[12$, с. 110, 111]. У філософській довідковій літературі принцип трактується як центральне поняття, основа системи, узагальнення й поширення будь-якого положення на всі явища тієї галузі, з якої цей принцип було абстраговано [13, с. 362]. Тобто поняття «принципи» слід розуміти як основні засади, вихідні ідеї, основу системи, що характеризується універсальністю і відображає суттєві положення правового явища. У загальному розумінні під принципом розуміється першооснова, основна ідея, основне правило поведінки. Принцип виступає загальнообов' язковою вимогою, відіграє роль регулятора суспільних відносин, є самостійним структурним елементом права.

Принципи управління, на думку Г. Атаманчука, це закономірність, відношення або взаємозв'язок елементів управління, що виражені у вигляді певного наукового положення, закріпленого в більшості своїй правом, і яке застосовується в теорії і практичній діяльності людей з управління [14]. Г. Пономаренко вказує, що деякі з принципів управління передбачають поглиблене вивчення об'єктивної потреби в ухваленні управлінських рішень, у правильному виборі засобів виконання завдань, в оптимальному визначенні змісту й форми ухваленого рішення з обов'язковим прогнозуванням можливих наслідків [15, с. 46]. У системі принципів управління в юридичній літературі розрізняють такі три взаємопов'язані та взаємозумовлені аспекти: 1) онтологічний; 2) гносеологічний; 3) методологічний. У першому випадку - це генезис принципів, який сприяє виявленню підстав та об'єктивних передумов, необхідних для систематизації принців управління. У другому аспекті - пов'язаний з аналізом характеру, логікою, структурою, наукової обґрунтованістю принципів, тобто $\epsilon$ науковим знанням про онтологію, що визначається поняттям принципу. І методологічний аспект розкриває роль та значення принців у теоретичній і практичній діяльності [14]. Вищенаведене можна застосувати і до системи принципів управління сектором безпеки України.

Отже, принципи управління закріплені здебільшого правовими приписами, мають значення в теорії і практичній діяльності, $є$ базисом виконання завдань та змісту ухваленого рішення. На наш погляд, під правовою конструкцією «принципи управління сектором безпеки» слід розуміти основні засади, вихідні ідеї, що визначають природу і соціальну сутність управління сектором безпеки, взаємозв'язок елементів управління, його спрямованість і найважливіші властивості.

Далі розглянемо класифікацію принципів управління сектором безпеки. Зазначимо, що єдиної класифікації принципів управління в юридичних джерелах не існує. Так, Г. Кунц та С. О’Доннел принципи управління пропонують розподіляти за такими групами: 1) принципи управління, 2) організації, 3) мотивації та 4) контролю [16]. Г. Атаманчук, досліджуючи проблеми управління як явища, класифікує принципи на такі групи: соціально-політичні, організаційні, організаційно-політичні, організаційно-технічні, економічні, організаційно-правові, загально-суттєві, видові, загальні, окремі, функціонально-структурні, організаційно-структурні, принципи державно-управлінської діяльності [14, с. 267]. Більшість науковців розрізняють три групи принципів управління (державного): загальносистемні, структурні та спеціалізовані [17, с. 38].

Д. Талалай зі співавторами здійснили розподіл принципів управління оперативно-службової діяльності 
Служби безпеки України на такі групи: суспільно-політичні та структурні, принципи управлінської діяльності. Суспільно-політичні принципи відображають та розкривають природу управління, його детермінованість і зумовленість суспільством. Систему цих принципів складають верховенство права, законність, прозорість, гласність та відкритість для демократичного контролю, об'єктивність та інші. Структурні принципи, що синтезовані через дослідження функціональної та організаційної структур управління, застосування яких притаманне для побудови організаційної структури управління (системний принцип, принцип територіальності та інші). Принципи управлінської діяльності, що розкривають відносини та взаємозв'язки методів, форм, стадій та інших елементів діяльності суб'єктів управлінської діяльності під час здійснення ними відповідних управлінських функцій [2].

С. Мельник, досліджуючи принципи військового управління, виділив загальні, тобто ті загальнообов'язкові вимоги, якими мають керуватися всі суб'єкти управління незалежно від свого статусу, і принципи управління на рівні галузі (галузеві принципи) або на статусному рівні - інституційному, організаційному, груповому. Із загальних розрізняють принципи законності управлінської діяльності, соціальної спрямованості, об'єктивності, комплексності, системності і гласності. До специфічних принципів військового управління автор відніс принципи централізації керівництва, єдиноначальності й суворої військової дисципліни. Крім того, існують також принципи, безпосередньо пов'язані з діяльністю суб'єктів, які реалізують військове управління [4, с. 107].

У подальшому розглянемо принципи, що передбачені в нормативно-правових актах у сфері національної безпеки, принципи діяльності Служби безпеки України, а також принципи розвитку сектору безпеки і оборони в співвідношенні з принципами управління сектором безпеки. Так, основним законодавчим актом у забезпеченні національної безпеки $\epsilon$, беззаперечно, Закон України «Про національну безпеку України». Згідно зі ст. 3 цього Закону передбачені принципи державної політики у сферах національної безпеки і оборони, до яких законодавець відносить:

1) верховенство права, підзвітність, законність, прозорість та дотримання засад демократичного цивільного контролю за функціонуванням сектору безпеки і оборони та застосуванням сили;

2) дотримання норм міжнародного права, участь в інтересах України у міжнародних зусиллях з підтримання миру і безпеки, міждержавних системах та механізмах міжнародної колективної безпеки;

3) розвиток сектору безпеки і оборони як основного інструменту реалізації державної політики у сферах національної безпеки і оборони [8].

Концепцією розвитку сектору безпеки і оборони України, затвердженою Указом Президента України від 14 березня 2016 року № 92/2016 врегульовано, що розвиток цієї системи спрямований на забезпечення керівництва ним як цілісної системи, що побудована на таких принципах:

- налагодження співробітництва та ефективні стратегічні комунікації між суб'єктами сектору безпеки і оборони; залучення громадянського суспільства до прийняття найбільш важливих стратегічних рішень з питань забезпечення національної безпеки;

чітка регламентація діяльності у секторі безпеки і оборони, що гарантує стабільний розвиток держави;

- застосування адаптивних стратегій управління, які передбачають залучення незалежних експертних організацій;

- прозорість та підзвітність суспільству [18].

Також відзначимо, що згідно з положеннями ст. 3 Закону України «Про Службу безпеки України» не визначено і не застосовується термін «принцип», а використовується натомість - «засади». Так, діяльність Служби безпеки України, іï̈ органів і співробітників ґрунтується на засадах законності, поваги до прав і гідності особи, позапартійності та відповідальності перед народом України. В оперативно-службовій діяльності Служба безпеки України дотримується принципів поєднання єдиноначальності і колегіальності, гласності і конспірації [19].

Отже, констатуючи відсутність єдиного підходу до класифікації принципів управління загалом, беручи до уваги особливості сектору безпеки України та його суб'єктів, сформована авторська позиція щодо класифікації принципів управління сектору безпеки України, яка враховує його багатосуб'єктність та відображає ці специфічні особливості.

Так, принципи управління сектором безпеки України можуть бути базові загальносистемні (законність, об'єктивність, верховенство права, системність, комплексність, повнота, гласність, підзвітність, прозорість, соціальної спрямованості, поваги до прав і гідності особи, відкритість для демократичного контролю, дотримання норм міжнародного права), структурні (організаційно-структурний принцип, функціонально-структурний принцип, принцип територіальності та інші) та спеціалізовані (поєднання єдиноначальності і колегіальності, централізації керівництва, дисципліни) та інші. Зазначимо, що наведений перелік принципів управління сектором безпеки України у статті не $є$ вичерпним, оскільки управління сектором безпеки $€$ багатогранною діяльністю і має багатосуб'єктний склад.

Підсумовуючи вищенаведене в нашому дослідженні, слід зробити такі висновки. Принципи визначають вимоги до системи, структури, організації і процесу управління сектором безпеки України.

Під терміном «принципи управління сектором безпеки» слід розуміти основні засади, вихідні ідеї, що визначають природу і соціальну сутність управління сектором безпеки, його спрямованість і найважливіші властивості. Принципи управління сектором безпеки доцільно поділити на групи: базові загальносистемні, структурні та спеціалізовані. Принципи управління сектором безпеки покликані відображати закономірності, об'єктивно існуючі в правовому регулюванні, що мають особливе значення для організації й здійснення захисту безпеки особи, суспільства та держави. Удосконалення принципів управління сектором безпеки України повинно мати комплексний характер, формувати правильні підходи до створення базових ідей його побудови та відповідати вимогам сучасної української правової доктрини та практики. 


\section{Правове забезпечення адміністративної реформи}

\section{Література}

1. Нижник Н.Р. Україна -Талалай Д., Шаптала О., Радченко О. Службово-бойова діяльність Служби безпеки України: проблеми принципів управління. Вісник Національної академії Державної прикордонної служби України. 2017. Вип. 1. URL. file:///C:/Users/1722/Downloads/ Vnadpsdu_2017_1_17\%20(2).pdf.

2. Сіцінська М.В. Сутність та особливості моделі державного управління у сфері демократичного цивільного контролю над сектором безпеки і оборони України. Економіка та держава. 2014. № 9. С. 98-100. URL: http://www.economy.in.ua/pdf/9_2014/25.pdf.

3. Мельник С.М. Принципи військового управління: адміністративно-правовий аспект. Підприємництво, господарство і право. 2019. 7. С. 104-107.

4. Антонов В.О. Місце та роль загальних (діалектико-матеріалістичних) принципів у системі забезпечення національної безпеки. Держава і право. Вип. 63. 2014. С. 75-81.

5. Пономарьов С.П. Адміністративно-правове забезпечення діяльності сектору безпеки і оборони України : автореф. ... докт. юрид. наук, 2018. URL. https://dduvs.in.ua/ wp-content/uploads/files/Structure/science/rada/ auto/25/1.pdf.

6. Пилипишин В.П. Поняття та основні риси державного управління. Юридична наука і практика. 2011. № 2. С. 10-14.

7. Про національну безпеку: Закон України від 21.06.2018 № 2469-VIII Відомості Верховної Ради України. 2018. № 31. Ст.241.

8. Чорний В.С. Особливості демократичного цивільного контролю над військовою сферою українського суспільства на сучасному етапі. Social development \& Security. 2018. № 3 (5). C. 3-13. URL: http://paperssds.eu/index.php/ JSPSDS/article/view/41/38.

9. Пономарьов С.П. Поняття та сутність сектору безпеки. Право.ua. 2015. № 3. С.69 -73. file:///C:/Users/1722/ Downloads/pravo_2015_3_13.pdf.
10. Енциклопедія державного управління : Т. 1 : Теорія державного управління /наук. -ред. кол. : В.М. Князев [та ін.], Нац. акад. держ. упр. при Президентові України. Київ : НАДУ, 2011. 597 с.

11. Юридична енциклопедія: В 6-ти т. Т. 5: П С. / голова ред-кол.: Ю.С. Шемшученко. Київ : Укр. енцикл., 1998. 2003. 736 с.

12. Философский энциклопедический словарь / ред.-сост.: Е.Ф. Губский, Г.В. Кораблева, В.А. Лутченко. Москва : Изд-во ИНФРА-М, 2006. С. 362.

13. Атаманчук Г.В. Теория государственного управления: Курс лекций. Москва : Юрид. лит-ра, 1997. 400 с.

14. Пономаренко Г.О. Управління у сфері забезпечення внутрішньої безпеки держави: адміністративно-правові засади: монографія. Харків : Вид. ФОП Вапнярчук Н.М., 2007. 246 c.

15. Кунц Г., С. О’Доннел. Управление: системный и ситуационный анализ управленческих решений. Т. 2. : Пер. с англ. Москва : Прогресс, 1981. 512 с.

16. Державне управління: Навч. посіб. За ред. А.Ф. Мельник. Київ : Знання-Прес, 2003. 343 с.

17. Про рішення Ради національної безпеки і оборони України від 4.03. 2016 року «Про Концепцію розвитку сектору безпеки і оборони України» Указ Президента України №92/2016. URL: https://zakon.rada.gov.ua/laws/ show/92/2016.

18. Про службу безпеки України: Закон України від 25.03.1992 № 2229-XII. Відомості Верховної Ради. 1992. № 27. Ст. 382.

Гончаренко Г. А., кандидат юридичних наук, доцент, доцент спеціальної кафедри № 1 «Правові засади державної безпеки» Інституту підготовки юридичних кадрів для Служби безпеки України Національного юридичного університету імені Ярослава Мудрого 